\title{
Epidemiology and outcomes of 655 diabetic foot patients in a Brazilian university hospital
}

\author{
Ligia de Loiola Cisneros", Rafael Henrique Rodrigues Costa, Tulio Pinho Navarro \\ From 20th Brazilian Diabetes Society Congress \\ Porto Alegre, Brazil. 11-18 November 2015
}

\section{Background}

Diabetic foot infections are a feared diabetic complication once it is associated to high amputation rates. The vascular surgeon plays a special role assessing and treating macrovascular impairments in order to avoid major amputations and death.

\section{Objective}

Assessment of the epidemiological data and outcomes rates of mortality, hospital readmissions and limb salvage-of patients with diabetic foot infections treated in a tertiary university hospital in Brazil.

\section{Materials and methods}

From January/2007 to December/2012, 655 patients with diabetic foot infections or ulcers were admitted at the vascular surgery unit. Retrospective medical records were reviewed and analyzed. The predictors for lower limb amputation and death were determined using the conditional logistic regression model analysis.

\section{Results}

Sixty seven percent (442) were males; the age ranged from 21 to 102 years (median 63 years). Arterial ischemia was present in $28 \%$ of the patients. Among these diabetic patients $73 \%$ had hypertension and $30 \%$ were active smokers. The in-hospital mortality rate was $12 \%$, and there was no statistically difference between patients with ischemic and non-ischemic lesions $(\mathrm{P}=0.16)$. Of the 576 patients alive, $61 \%$ were not readmitted, $21 \%$ were readmitted once and $18 \%$ were readmitted twice or more times. The minor amputation rate was $48 \%$ while major amputations were performed in $21 \%$ of the subjects (28\% below the knee amputation and $72 \%$ above the knee amputation). The major amputation free

\footnotetext{
* Correspondence: ligialoyola@gmail.com

Universidade Federal de Minas Gerais, Belo Horizonte, Brazil
}

survival rate was $72 \%$. After discharge $47 \%$ of the patients required special home-care for dressings and for parenteral drug administration. Independent risk factor for amputation were age (OR: 1.02; 95\%CI: 1.0011.035; $\mathrm{P}=0.041)$ and arterial ischemia (OR 2.20; $95 \% \mathrm{CI}$ 1.46-3.31; $\mathrm{P}<0.0001)$. Independent risk factors for death were age (OR 1.06; 95\% CI $1.03-1.08 ; \mathrm{P}<0.01)$ and major amputations (OR 2.38; 95\% CI 1.41 - 3.99; $\mathrm{P}=0.01$ ).

\section{Conclusion}

Diabetic foot is a severe condition with high mortality and amputation rates. Conditions associated with limb loss were age and ischemia. The independent risk factors for death were age and major amputation.

Published: 11 November 2015

doi:10.1186/1758-5996-7-S1-A20

Cite this article as: de Loiola Cisneros et al:: Epidemiology and outcomes of 655 diabetic foot patients in a Brazilian university hospital.

Diabetology \& Metabolic Syndrome 2015 7(Suppl 1):A20.

Submit your next manuscript to BioMed Central and take full advantage of:

- Convenient online submission

- Thorough peer review

- No space constraints or color figure charges

- Immediate publication on acceptance

- Inclusion in PubMed, CAS, Scopus and Google Scholar

- Research which is freely available for redistribution 